\title{
COMPARATIVE PHYSIOLOGICAL RESPONSE OF SAINFOIN (ONOBRYCHIS VICIAEFOLIA) SEEDLINGS TO ALKALINE AND SALINE-ALKALINE STRESS
}

\author{
G.-Q. $\mathrm{Wu}^{1 *}, \mathrm{H} . \mathrm{Li}^{1}$, Y.-H. Zhu ${ }^{1}$ and S.-J. $\mathrm{Li}^{1}$ \\ ${ }^{1}$ School of Life Science and Engineering, Lanzhou University of Technology, Lanzhou 730050, China \\ Corresponding author’s E-mail: gwwu@lut.edu.cn; wugq08@126.com
}

\begin{abstract}
Salt-alkali stress is a major environmental factor that seriously limits crops development and productivity worldwide. The objective of this study is to compare growth and physiological responses of sainfoin (Onobrychis viciaefolia) to alkali $\left(\mathrm{NaHCO}_{3}\right)$ and salt-alkali $\left(\mathrm{NaCl}: \mathrm{NaHCO}_{3}\right)$ stress, by investigating biomass, photosynthetic pigments, antioxidant enzymes, inorganic ions, organic substances such as proline and sugars. It was shown that both alkaline and salinealkaline stress treatments significantly reduced fresh weight $(\mathrm{FW})$ and dry weight (DW), chlorophyll (Chl) contents, $\mathrm{K}^{+}$ concentrations, antioxidant enzymes activity and soluble sugars contents, whereas clearly increased malondialdehyde (MDA), proline and $\mathrm{Na}^{+}$concentrations in sainfoin plants compared with control (no added $\mathrm{NaCl}$ and $\mathrm{NaHCO}_{3}$ ). It is also observed that in the $150 \mathrm{mM} \mathrm{NaHCO}$, peroxidase (POD) activity, soluble sugar contents and $\mathrm{K}^{+} / \mathrm{Na}^{+}$ratio in plants under $\mathrm{NaHCO}_{3}$ treatment were lower than those in plants under $\mathrm{NaCl}: \mathrm{NaHCO}_{3}$ treatment. These results suggested that the damages caused by alkaline stress on the growth of sainfoin plants are more serious than those caused by salinealkaline stress treatments. The findings of the present work provide a basis for understanding the physiological responses to saline-alkaline stress in forage legumes.
\end{abstract}

Key words: Forage legume; antioxidant enzymes; proline; soluble sugars; malondialdehyde

https://doi.org/10.36899/JAPS.2021.4.0299

Published online December 15, 2020

\section{INTRODUCTION}

Soil salinization is becoming a serious problem in agricultural systems and is one of major factors which limits crop productivity worldwide ( $\mathrm{Li}$ et al., 2020). Saline stress is primarily caused by $\mathrm{NaCl}$ and/or $\mathrm{Na}_{2} \mathrm{SO}_{4}$ accumulation, while alkaline stress is mainly caused by $\mathrm{NaHCO}_{3}$ and $\mathrm{Na}_{2} \mathrm{CO}_{3}$ accumulation (Zhang et al., 2019). In northwest China, more than $70 \%$ of the agriculture area is threatened by saline-alkaline stress (Jia et al., 2019). It is well-known that alkaline stress or salinealkaline stress can inhibit plants growth and development more seriously than neutral-salt stress (Xu et al., 2019). Saline-alkali stress has a significant effect on chloroplast ultrastructure and photosynthetic components, which are considered to be non-stomatal factors that reduce photosynthetic capacity (Bejaoui et al., 2016; Sun et al., 2019). Salt and alkali stress also markedly decreased the chlorophyll (Chl) a and $\mathrm{Chl} \mathrm{b}$ contents in the leaves of plants (Zhang et al., 2019). Generally, Chl contents were more sensitive to alkaline stress than saline stress at the same concentration (Zhang et al., 2019). Alkaline stress has also been shown to inhibit uptake of anions such as $\mathrm{Cl}^{-}, \mathrm{NO}_{3}{ }^{-}, \mathrm{SO}_{4}{ }^{2-}$ and $\mathrm{H}_{2} \mathrm{PO}_{4}^{-}$, and significantly reduce the selective uptake and transport for $\mathrm{K}^{+}$over $\mathrm{Na}^{+}$(Wang et al., 2011). To cope with saline-alkaline stress, plants have evolved a variety of adaptive mechanisms such as osmotic adjustment (OA), accumulation of organic substances, antioxidant enzyme, and so on (Jia et al.,
2019). Soluble sugars, proline, malondialdehyde (MDA), superoxidase dismutase (SOD), catalase (CAT), peroxidase (POD) and ascorbate peroxidase (APX) play crucial roles in OA and might be of extreme importance in scavenging reactive oxygen species (ROS) when plants were subjected to salinity stress (Bejaoui et al., 2016; Khalid et al., 2020).

Sainfoin (Onobrychis viciaefolia), belonged to the Leguminosae family, is recognized as one of the most important forage legumes with high quality in the world (Bhattarai et al., 2018), and it is also praised as "the queen of forage". In China, sainfoin is mainly planted in the arid and semi-arid areas of northwest China, including Gansu province (Shen et al., 2019). Due to its high contents of condensed tannins, sainfoin has been documented to decrease parasites (such as roundworm and trematode) in ruminant digestive tracts and provides environmental benefits by decreasing emissions of methane from the ruminant animals (Bhattarai et al., 2018). Although sainfoin has good adaptability to abiotic environments, plants are sensitive to high salt conditions. The low concentrations $(5-50 \mathrm{mM})$ of $\mathrm{NaCl}$ had no significant effect on plant growth of sainfoin, whereas high concentrations (100 and $200 \mathrm{mM})$ of $\mathrm{NaCl}$ significantly inhibited growth compared to control (Wu et al., 2017a). However, the studies on effects of alkaline stress on growth and physiological responses in sainfoin plants have been rarely performed.

The objective of this work is to compare 
physiological responses of sainfoin to alkaline stress and saline-alkaline stress, by investigating biomass, photosynthetic pigments, antioxidant enzymes, inorganic ions, organic substances such as proline and sugars. The findings of the present study will provide a basis for understanding the physiological responses to salinealkaline stress in forage legume species.

\section{MATERIALS AND METHODS}

Plant materials, growth conditions and stress treatments: The seeds of sainfoin $(O$. viciaefolia Scop.) cultivar 'GANSU' were purchased from Lanzhou Xinglong Grass Technical Service Co., Ltd, Gansu province, China. The uniform seeds were selected and sowed into vermiculite (4 seeds/container) irrigated with the sterile water. After $3 \mathrm{~d}$ of germination, seedlings were irrigated with the modified Hoagland nutrition solution containing $0.5 \mathrm{mM} \mathrm{NH}_{4} \mathrm{H}_{2} \mathrm{PO}_{4}, 2 \mathrm{mM} \mathrm{KNO}_{3}, 0.1 \mathrm{mM} \mathrm{Ca}$ $\left(\mathrm{NO}_{3}\right)_{2}, 60 \mu \mathrm{M}$ Fe-Citrate, $0.25 \mathrm{mM} \mathrm{MgSO} 4,92 \mu \mathrm{M}$ $\mathrm{H}_{3} \mathrm{BO}_{3}, 1.6 \mu \mathrm{M} \mathrm{ZnSO}_{4} \cdot 7 \mathrm{H}_{2} \mathrm{O}, 18 \mu \mathrm{M} \mathrm{MnCl}_{2} \cdot 4 \mathrm{H}_{2} \mathrm{O}, 0.25$ $\mu \mathrm{M}\left(\mathrm{NH}_{4}\right)_{6} \mathrm{Mo}_{7} \mathrm{O}_{24} \cdot 4 \mathrm{H}_{2} \mathrm{O}$ and $0.6 \mu \mathrm{M} \mathrm{CuSO}_{4} \cdot 5 \mathrm{H}_{2} \mathrm{O}$. Solution was changed every $3 \mathrm{~d}$. Seedlings are grown in a growth chamber with the temperature of $18{ }^{\circ} \mathrm{C} / 24{ }^{\circ} \mathrm{C}$ (night/day), the light intensity of $400-500 \mu \mathrm{mol} / \mathrm{m}^{2} / \mathrm{s}$, and the relative humidity (RH) of 50-55\% (Wu et al., 2017b).

According to our previous studies ( $\mathrm{Wu}$ et al., 2019), four-week-old plants were challenged by alkali and salt-alkali stress treatments as follows: control (added neither salt nor alkaline, C), $50 \mathrm{mM} \mathrm{NaHCO}$ (alkali stress 1, AS1), $100 \mathrm{mM} \mathrm{NaHCO}_{3}$ (alkali stress 2, AS2), $150 \mathrm{mM} \mathrm{NaHCO} 3$ (alkali stress 3, AS3), $25 \mathrm{mM}$ $\mathrm{NaCl}+25 \mathrm{mM} \mathrm{NaHCO} 3$ (salt-alkali stress 1, SAS1), 50 $\mathrm{mM} \mathrm{NaCl}+50 \mathrm{mM} \mathrm{NaHCO} 3$ (salt-alkali stress 2, SAS2), and $75 \mathrm{mM} \mathrm{NaCl}+75 \mathrm{mM} \mathrm{NaHCO}_{3}$ (salt-alkali stress 3, SAS3). Salt composition of the treatments was shown in Table 1. Each treatment had eight biological repeats. Each repeat included three plants. Treatment solution was changed every $2 \mathrm{~d}$. After $7 \mathrm{~d}$ of alkali and salt-alkali stress treatments, plants were used to test physiological parameters.

Table 1. Concentrations $(\mathrm{mM})$ of various salts $(\mathrm{NaCl}$, $\mathrm{NaHCO}_{3}$ ) in treatments.

\begin{tabular}{ccccc}
\hline Treatment & $\begin{array}{c}\mathbf{N a C l} \\
(\mathbf{m M})\end{array}$ & $\begin{array}{c}\text { NaHCO3 } \\
(\mathbf{m M})\end{array}$ & $\begin{array}{c}\text { Salinity } \\
(\mathbf{m M})\end{array}$ & $\mathbf{p H}$ \\
\hline C & 0 & 0 & 0 & 6.85 \\
AS1 & 0 & 50 & 50 & 8.59 \\
AS2 & 0 & 100 & 100 & 8.60 \\
AS3 & 0 & 150 & 150 & 8.62 \\
SAS1 & 25 & 25 & 50 & 8.51 \\
SAS2 & 50 & 50 & 100 & 8.53 \\
SAS3 & 75 & 75 & 150 & 8.54 \\
\hline
\end{tabular}

C, control; AS, alkali stress $\left(\mathrm{NaHCO}_{3}\right)$; SAS, salt-alkali stress ( $\mathrm{NaCl}: \mathrm{NaHCO}_{3}$ ).
Determination of growth, $\mathrm{Na}^{+}$and $\mathrm{K}^{+}$concentrations, and chlorophyll contents: At the end of the alkali and salt-alkali stress treatments, to remove surface vermiculite, plant roots were washed four time with deionized water. Shoots and roots were separated and blotted; shoot and root fresh weight (FW) were measured immediately and then were dried in an oven at $80{ }^{\circ} \mathrm{C}$ for $72 \mathrm{~h}$ to determine dry weight (DW). Water content (WC) of tissue was calculated by following the formulas: WC $(\mathrm{g} / \mathrm{g} \mathrm{DW})=(\mathrm{FW}-\mathrm{DW}) / \mathrm{DW} . \mathrm{K}^{+}$and $\mathrm{Na}^{+}$were extracted from dried sample in $100 \mathrm{mM}$ acetic acid at $95^{\circ} \mathrm{C}$ for $2 \mathrm{~h}$. $\mathrm{K}^{+}$and $\mathrm{Na}^{+}$concentrations were assayed by using a flame spectrophotometer (2655-00, Cole-Parmer Instrument Co., Vernon Hills, USA). $\mathrm{K}^{+} / \mathrm{Na}^{+}$ratio was measured according to methods of Wang et al. (2009). Chlorophyll (Chl) contents were determined by using the methods of Zhang et al. (2019) with the slight modification. Briefly, $\mathrm{Chl} \mathrm{a}$ and $\mathrm{Chl} b$ were extracted from fresh leaves samples of $1.5 \mathrm{~g}$ by a mixture of ethanol, acetone, and $\mathrm{H}_{2} \mathrm{O}$ with a volumetric ratio of 4.5:4.5:1. The absorbances at 665 and $649 \mathrm{~nm}\left(\mathrm{~A}_{665}\right.$ and $\mathrm{A}_{649}$, respectively) were determined by using a spectrophotometer (UV- 300 OPC, Mapada Co., Shanghai, China). The contents of $\mathrm{Chl} \mathrm{a}$ and $\mathrm{Chl} \mathrm{b}$ were calculated by the following formulas: $\mathrm{Chl} \mathrm{a}(\mathrm{mmol} / \mathrm{g} \mathrm{FW})$ $=\left(13.95 \mathrm{~A}_{665}-6.88 \mathrm{~A}_{649}\right) \times V / 1000 \times \mathrm{FW}, \mathrm{Chl} \mathrm{b}(\mathrm{mmol} / \mathrm{g}$ $\mathrm{FW})=\left(24.96 \mathrm{~A}_{649}-7.32 \mathrm{~A}_{665}\right) \times V / 1000 \times \mathrm{FW}$, where $V$ is the volume of extraction, $\mathrm{FW}$ is fresh weight of leaves samples. The total $\mathrm{Chl}$ contents are sum of $\mathrm{Chl}$ a and $\mathrm{Chl}$ b.

Analysis of antioxidant enzymes and malondialdehyde: Superoxidase dismutase (SOD) was tested by measuring the capability of the enzyme to inhibit the photochemical decrease of nitro blue tetrazolium (NBT) reagent according to the methods described by Beauchamp and Fridovich (1971). Peroxidase (POD) was determined by monitoring the increase in absorbance at wavelength of $470 \mathrm{~nm}$ recorded $40 \mathrm{~s}$ after the additional $\mathrm{H}_{2} \mathrm{O}_{2}$ according to the methods of Sakharov and Ardila (1999). Catalase (CAT) was analyzed by measuring the amount of $\mathrm{H}_{2} \mathrm{O}_{2}$ consumed during the reaction process with the methods of Aebi (1984). Ascorbate peroxidase (APX) was determined by monitoring the increase in absorbance at $290 \mathrm{~nm}$ recorded $60 \mathrm{~s}$ after the additional $\mathrm{H}_{2} \mathrm{O}_{2}$ according to the methods of Nakano and Asada (1981) with the slight modification. Malondialdehyde (MDA) concentration was tested by following the methods described by Bao et al. (2009).

Determination of proline and soluble sugar contents: Proline concentrations were measured by using ninhydrin reagent based on the methods described by Bates et al. (1973). Soluble sugars were tested by using the anthrone ethyl acetate reagent according to the methods of Zhang et al. (2006) with the slight modification. The contents of sucrose, glucose, and fructose were tested by using the resorcinol, sodium arsenomolybdate, and resorcinol 
reagents, respectively, according to the method of Liu et al. (2008).

Statistical analysis: All data were subjected to a oneway analysis of variance (ANOVA) using SPSS (v. 19.0, SPSS Inc., Chicago, IL, USA), and the mean differences were compared by with Duncan's multiple range test at $P$ $<0.05$. Data were represented as the mean \pm standard error $(\mathrm{SE})$ in the tables and figures.

\section{RESULTS AND DISCUSSION}

Effects of alkaline and salt-alkali stress treatments on growth of sainfoin: Phenotypically, growth of plants was remarkedly inhibited under either alkaline stress (SA) or salt-alkaline stress (SAS) compared to control (C), whereas SAS-treated plants grew relatively better than SA-treated plants (Fig. 1).

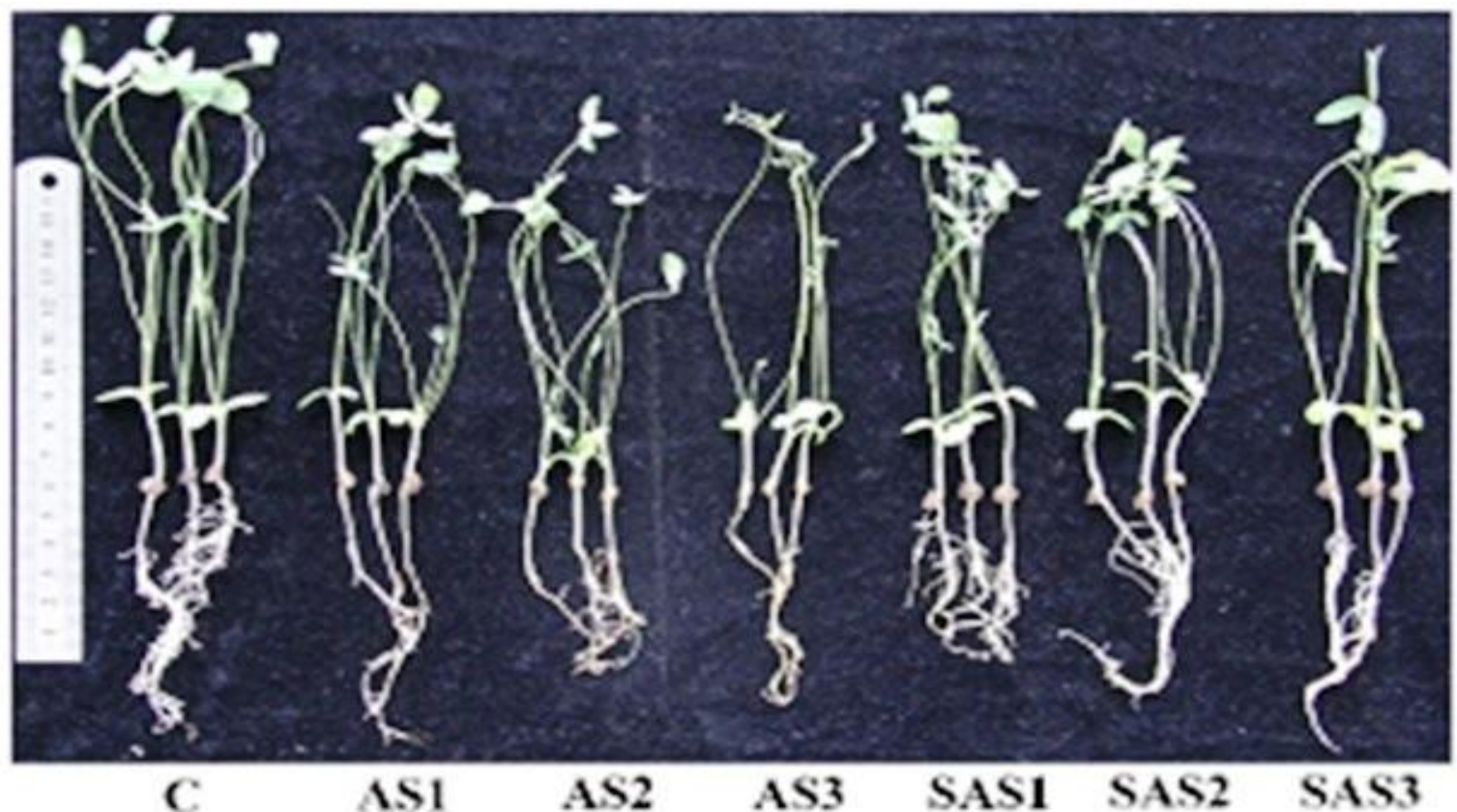

Fig. 1. Phenotypes of sainfoin under alkaline stress and salt-alkaline stress. Four-week-old seedlings were treated with modified Hoagland nutrient solution supplemented without (control, C) or with $50 \mathrm{mM} \mathrm{NaHCO}_{3}$ (alkali stress 1, AS1), $100 \mathrm{mM} \mathrm{NaHCO}$ (alkali stress 2, AS2), $150 \mathrm{mM} \mathrm{NaHCO}$ (alkali stress 2, AS2), 25 mM NaCl+25 mM NaHCO 3 (salt-alkali stress 1, SAS1), $50 \mathrm{mM} \mathrm{NaCl+50} \mathrm{mM} \mathrm{NaHCO}_{3}$ (salt-alkali stress

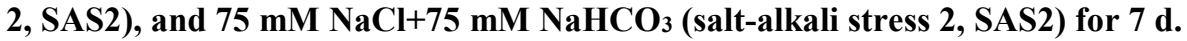

Biomass accumulation on plants is an optimum parameter for evaluating plant stress (Alvarez-Acosta et al., 2018). Shoot fresh weight (FW) and dry weight (DW) were observably lower in plants subjected to both alkali and salt-alkali stresses, compared with control $(P<0.05)$. High alkali stress (150 mM $\left.\mathrm{NaHCO}_{3}, \mathrm{AS} 3\right)$ significantly reduced shoot water content compared with control $(P<$ $0.05)$, while salt-alkali stresses have no significant effects on shoot water content. Root FW was observably lower in plants exposed to AS2, AS3, SAS2 and SAS3 treatments than in control plants $(P<0.05)$. AS3 treatment also significantly decreased root DW compared to control $(P<0.05)$, whilst salt-alkali stresses did not have any effects on root DW compared with control (Table 2). Additionally, shoot water content in SA3treated plants were lower than that in untreated plants (Table 2).
$\mathrm{Chl}$ is the major photosynthetic pigment, which plays critical roles in the absorption, transformation, and transmission of light (Zhang et al., 2019). In our study, the total $\mathrm{Chl}$ contents displayed a significant decrease in plants leaves under all the alkali and salt-alkali stresses compared with control $(P<0.05)$ (Fig. 2a). It may because stresses disturbed the balance between the biosynthesis and degradation of $\mathrm{Chl}$, and thus limited $\mathrm{Chl}$ synthesis (Jia et al., 2019). This is in accordance with the findings in avocados (Persea americana) and Goji berry (Lycium barbarum) by Alvarez-Acosta et al. (2018) and Zhang et al. (2019). Besides, AS2, AS3 and SAS3 treatments also clearly reduced ratio of $\mathrm{Chl} \mathrm{a} / \mathrm{Chl} \mathrm{b}$ in leaves of plants compared to control, and the value of $\mathrm{Chl}$ $\mathrm{a} / \mathrm{Chl} \mathrm{b}$ in plants under SAS2 treatment was $92.7 \%$ higher than that in plants under AS2 treatment $(P<0.05)$ (Fig. 2b). 

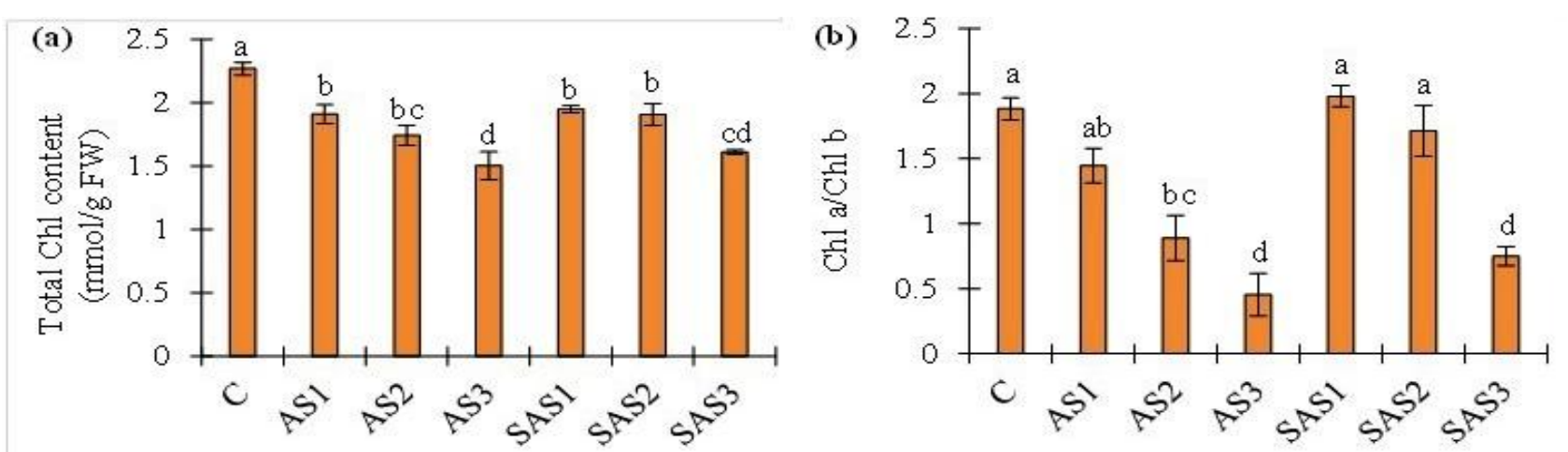

Fig. 2. Effects of alkaline and salt-alkaline stresses on total Chl content (a) and Chl a/Chl b ratio (b) in shoot of sainfoin. Four-week-old seedlings were treated with modified Hoagland nutrient solution supplemented without (control, C) or with $50 \mathrm{mM} \mathrm{NaHCO}_{3}$ (alkali stress 1, AS1), $100 \mathrm{mM} \mathrm{NaHCO}$ (alkali stress 2 , AS2), 150 mM $\mathrm{NaHCO}_{3}$ (alkali stress 2, AS2), $25 \mathrm{mM} \mathrm{NaCl+25} \mathrm{mM} \mathrm{NaHCO}$ (salt-alkali stress 1, SAS1), $50 \mathrm{mM} \mathrm{NaCl}+50 \mathrm{mM} \mathrm{NaHCO}$ (salt-alkali stress 2, SAS2), and $75 \mathrm{mM} \mathrm{NaCl}+75 \mathrm{mM} \mathrm{NaHCO}$ (salt-alkali stress 2, SAS2) for $7 \mathrm{~d}$. Three plants were pooled in each replicate. Values are means $\pm \mathrm{SE}(n=8)$ and bars represent SE. Columns with different letters represent significant differences at $P<0.05$ (Duncan's test). FW - fresh weight.

This may because high-pH will disorder the ion homeostasis and plants do not uptake metal ions $\left(\mathrm{Fe}^{2+}\right.$ and $\mathrm{Mg}^{2+}$ ) needed to synthesize Chl (Jia et al., 2019). These results implied that harmful effects of alkaline on sainfoin plants are stronger than those of salt-alkali stress.

Effects of alkaline and salt-alkali stress treatments on antioxidant enzymes and MDA of sainfoin: Under stressed condition, plants will produce a lot of ROS, causing damage to membrane lipid peroxidation. Plants have developed a ROS-scavenging system that includes antioxidant substances and antioxidant enzymes to alleviate oxidative stress (Gong et al., 2013). SOD is an important antioxidant enzyme for the removal of ROS, which can dismutase $\mathrm{O}_{2}{ }^{\cdot-}$ to $\mathrm{H}_{2} \mathrm{O}_{2}$ and oxygen, then CAT and POD turn $\mathrm{H}_{2} \mathrm{O}_{2}$ into water and oxygen (Sun et al., 2019). APX, another important antioxidant enzyme, uses ascorbate as the electron donor for the decrease of $\mathrm{H}_{2} \mathrm{O}_{2}$ (Gong et al., 2013). In the present study, AS1, AS2, AS3, SAS2 and SAS3 significantly reduced activities of SOD, POD, CAT and APX in leaves compared to control $(P<$ 0.05) (Fig. 3a, b, c, d).

These effects because alkaline and salt-alkali stresses block the pathway of enzymes synthesis and reduce the activities of enzymes (Zhang et al., 2019). Interestingly, in $150 \mathrm{mM} \mathrm{NaHCO}$, activity of POD was significantly higher in plants under SAS3 treatment than that under AS3 treatment $(P<0.05)$ (Fig. 3b), thus indicating that POD activity of sainfoin plants has stronger adaptability to saline-alkaline stress compared to alkaline stress. MDA is a key sign of membrane lipid peroxidation damage in plants (Bao et al., 2009). In the treatment of $150 \mathrm{mM} \mathrm{NaHCO}$, both AS3) and SAS3 treatments significantly increased leaf MDA concentration by 3.4 - and 3.1-fold compared to control $(P$
$<0.05)$. However, in the treatment of $100 \mathrm{mM} \mathrm{NaHCO}_{3}$, MDA concentration was significantly increased by alkaline stress $(\mathrm{AS} 2)(P<0.05)$, but not salt-alkali stress (Fig. 4a), which showed that sainfoin plants suffered severe oxidative damage under alkaline stress.

Effects of alkaline and salt-alkali stress treatments on proline and soluble sugar contents of sainfoin saltalkali: Under abiotic stresses, plants can accumulate compatible solutes such as proline and sugars to regulate osmotic balance and enhance plant tolerance to stressed conditions (Sperdouli and Moustakas, 2012). In the present study, both AS3 and SAS3 treatments remarkably enhanced proline concentrations in leaves compared to control $(P<0.05)$ (Fig. 4b). Similar results were found in Malus halliana (Jia et al., 2019), where proline was significantly accumulated in leaves of plants under alkaline and salinity-alkaline stresses, indicating that the accumulation of proline was a product of damage from stresses. It was found that soluble sugars concentration of shoot was significantly decreased in plants subjected to AS3 and SAS3 treatments compared to control, and the values in plant under SAS3 treatment were remarkably higher than in plants under SA3 treatment (Fig. 5a). Similar reduction of sugars concentration was observed in sainfoin plants subjected to salt stress (Wu et al., 2017b). Four treatments (AS2, AS3, SAS2, and SAS3) significantly reduced the contents of sucrose compared to control (Fig. 5b). Furthermore, the contents of fructose were observably lower under AS1, AS2, AS3, SAS2, and SAS3 treatment than those under control condition (Fig. $5 \mathrm{c})$. Either alkaline or salt-alkali stresses significantly decreased glucose contents compared to control (Fig. 5d).

These results suggested that alkaline and saltalkali stresses may inhibit sugars synthesis and reduce 
sugars accumulation. In conclusion, our results showed that both alkaline stress and saline-alkaline stress significantly reduced $\mathrm{FW}$ and $\mathrm{DW}, \mathrm{Chl}$ contents, $\mathrm{K}^{+}$ concentration, antioxidant enzymes activity and sugars contents, while clearly increased MDA, proline and $\mathrm{Na}^{+}$ concentrations in sainfoin plants compared with control.
It is also observed that in the $150 \mathrm{mM} \mathrm{NaHCO}$, POD activity, soluble sugars contents and $\mathrm{K}^{+} / \mathrm{Na}^{+}$ratio in plants under $\mathrm{NaHCO}_{3}$ treatment were lower than those in plants under $\mathrm{NaCl}: \mathrm{NaHCO}_{3}$ treatment. These results suggested that the damages caused by alkaline stress were more serious than those caused by saline-alkaline stress.

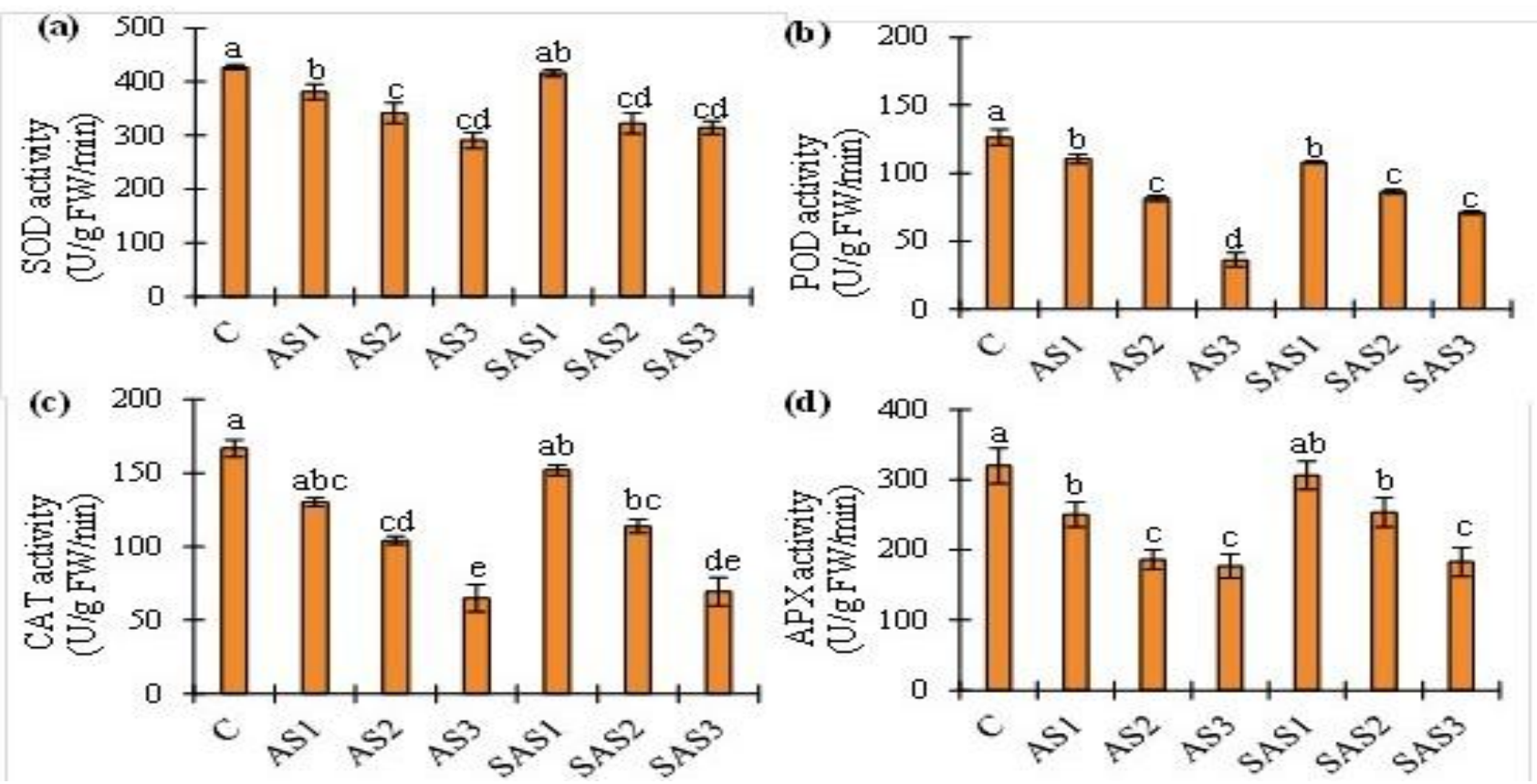

Fig. 3. Effects of alkaline and salt-alkaline stresses on SOD (a), POD (b), CAT (c), and APX (d) activity of shoot in sainfoin. Four-week-old seedlings were treatment with modified Hoagland nutrient solution supplemented without (control, C) or with $50 \mathrm{mM} \mathrm{NaHCO}_{3}$ (alkali stress 1, AS1), $100 \mathrm{mM} \mathrm{NaHCO}_{3}$

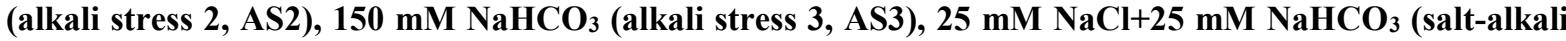
stress 1, SAS1), $50 \mathrm{mM} \mathrm{NaCl+50} \mathrm{mM} \mathrm{NaHCO}$ (salt-alkali stress 2, SAS2), and $75 \mathrm{mM} \mathrm{NaCl+75} \mathrm{mM}$ $\mathrm{NaHCO}_{3}$ (salt-alkali stress 3, SAS3) for $7 \mathrm{~d}$. Three plants were pooled in each replicate. Values are means \pm SE $(n=8)$ and bars represent SE. Columns with different letters represent significant differences at $P<$ 0.05 (Duncan's test). FW - fresh weight.
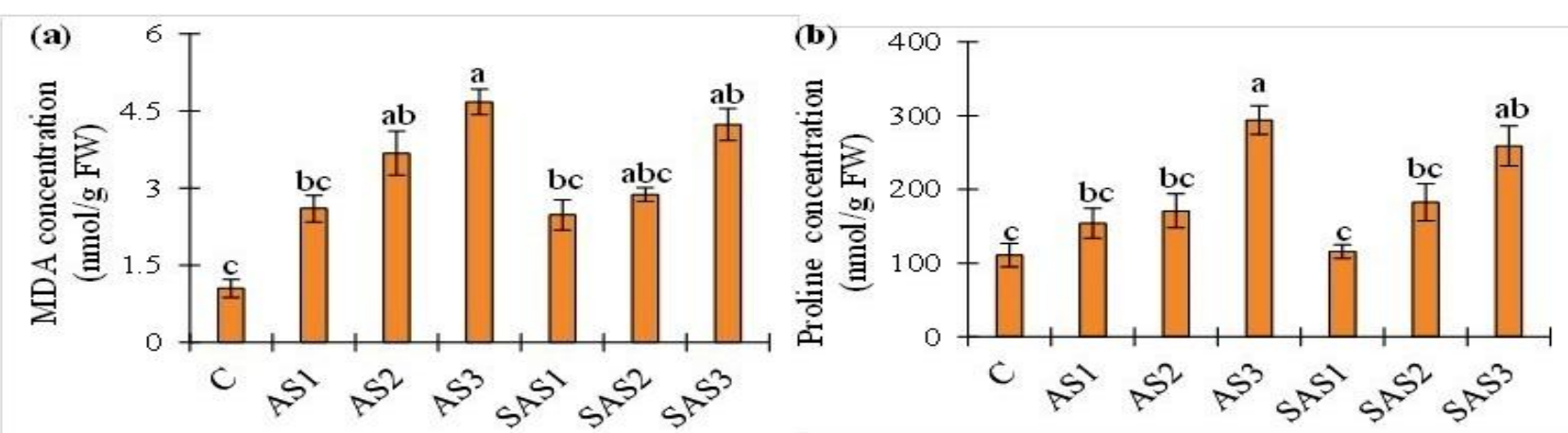

Fig. 4. Effects of alkaline and salt-alkaline stresses on MDA (a) and proline (b) concentrations of shoot in sainfoin. Four-week-old seedlings were treated with modified Hoagland nutrient solution supplemented without (control, C) or with $50 \mathrm{mM} \mathrm{NaHCO}$ (alkali stress 1, AS1), $100 \mathrm{mM} \mathrm{NaHCO}$ (alkali stress 2, AS2), 150 mM NaHCO 3 (alkali stress 3, AS3), $25 \mathrm{mM} \mathrm{NaCl+25} \mathrm{mM} \mathrm{NaHCO}$ (salt-alkali stress 1, SAS1), 50 mM $\mathrm{NaCl}+50 \mathrm{mM} \mathrm{NaHCO}$ (salt-alkali stress 2, SAS2), and $75 \mathrm{mM} \mathrm{NaCl+75} \mathrm{mM} \mathrm{NaHCO}_{3}$ (salt-alkali stress 3 , SAS3) for $7 \mathrm{~d}$. Three plants were pooled in each replicate. Values are means $\pm \mathrm{SE}(n=8)$ and bars represent SE. Columns with different letters represent significant differences at $P<0.05$ (Duncan's test). FW - fresh weight. 
Table 2. Effects of alkaline and salt-alkali stresses on fresh weight, dry weight and water content of shoot and root in sainfoin. Four-week-old seedlings were treated with modified Hoagland nutrient solution supplemented without (control, C) or with $50 \mathrm{mM}$ (alkali stress 1, AS1), $100 \mathrm{mM} \mathrm{NaHCO} 3$ (alkali stress 2, AS2), 150 mM NaHCO 3 (alkali stress 3, AS3), 25 mM NaCl+25 mM NaHCO 3 (salt-alkali stress 1, SAS1), $50 \mathrm{mM} \mathrm{NaCl}+50 \mathrm{mM} \mathrm{NaHCO}_{3}$ (salt-alkali stress 2, SAS2), and $75 \mathrm{mM} \mathrm{NaCl}+75 \mathrm{mM} \mathrm{NaHCO}_{3}$ (salt-alkali stress $3, \mathrm{SAS3})$ for $7 \mathrm{~d}$. Three plants were pooled in each replicate. Values are means $\pm \operatorname{SE}(n=8)$. Within each column, means followed by different letters are significantly different at $P<0.05$ (Duncan's test).

\begin{tabular}{lcccccc}
\hline Treatment & \multicolumn{3}{c}{ Shoot } & \multicolumn{3}{c}{ Root } \\
\cline { 2 - 7 } & $\begin{array}{c}\text { Fresh weight } \\
\text { (mg/plant) }\end{array}$ & $\begin{array}{c}\text { Dry weight } \\
\text { (mg/plants) }\end{array}$ & $\begin{array}{c}\text { Water content } \\
\text { (g/g DW) }\end{array}$ & $\begin{array}{c}\text { Fresh weight } \\
\text { (mg/plant) }\end{array}$ & $\begin{array}{c}\text { Dry weight } \\
\text { (mg/plants) }\end{array}$ & $\begin{array}{c}\text { Water content } \\
\text { (g/g DW) }\end{array}$ \\
\hline $\mathrm{C}$ & $205.03 \pm 9.81 \mathrm{a}$ & $19.05 \pm 1.07 \mathrm{a}$ & $9.83 \pm 0.25 \mathrm{a}$ & $74.64 \pm 10.97 \mathrm{a}$ & $3.55 \pm 0.37 \mathrm{a}$ & $21.11 \pm 2.06 \mathrm{a}$ \\
$\mathrm{AS} 1$ & $163.45 \pm 4.94 \mathrm{bc}$ & $16.56 \pm 0.89 \mathrm{bc}$ & $9.12 \pm 0.73 \mathrm{ab}$ & $61.27 \pm 4.22 \mathrm{abc}$ & $3.16 \pm 0.22 \mathrm{ab}$ & $19.10 \pm 2.07 \mathrm{a}$ \\
$\mathrm{AS} 2$ & $149.22 \pm 3.11 \mathrm{~cd}$ & $15.17 \pm 0.45 \mathrm{bc}$ & $8.89 \pm 0.32 \mathrm{ab}$ & $50.45 \pm 0.99 \mathrm{bcd}$ & $2.83 \pm 0.12 \mathrm{ab}$ & $17.17 \pm 1.08 \mathrm{a}$ \\
$\mathrm{AS} 3$ & $126.85 \pm 4.19 \mathrm{e}$ & $14.45 \pm 0.49 \mathrm{c}$ & $7.86 \pm 0.44 \mathrm{~b}$ & $43.95 \pm 2.75 \mathrm{~d}$ & $2.60 \pm 0.22 \mathrm{~b}$ & $17.24 \pm 2.50 \mathrm{a}$ \\
$\mathrm{SAS} 1$ & $171.10 \pm 7.06 \mathrm{~b}$ & $16.84 \pm 0.51 \mathrm{~b}$ & $9.17 \pm 0.33 \mathrm{ab}$ & $65.29 \pm 3.41 \mathrm{ab}$ & $3.30 \pm 0.42 \mathrm{ab}$ & $21.16 \pm 1.97 \mathrm{a}$ \\
$\mathrm{SAS} 2$ & $153.05 \pm 4.67 \mathrm{bcd}$ & $16.11 \pm 0.66 \mathrm{bc}$ & $8.65 \pm 0.54 \mathrm{ab}$ & $56.33 \pm 2.76 \mathrm{bcd}$ & $3.19 \pm 0.24 \mathrm{ab}$ & $17.23 \pm 1.28 \mathrm{a}$ \\
$\mathrm{SAS} 3$ & $135.09 \pm 6.17 \mathrm{de}$ & $15.07 \pm 4.56 \mathrm{bc}$ & $8.03 \pm 0.50 \mathrm{ab}$ & $47.93 \pm 4.33 \mathrm{~cd}$ & $2.95 \pm 0.31 \mathrm{ab}$ & $16.03 \pm 1.65 \mathrm{a}$ \\
\hline
\end{tabular}
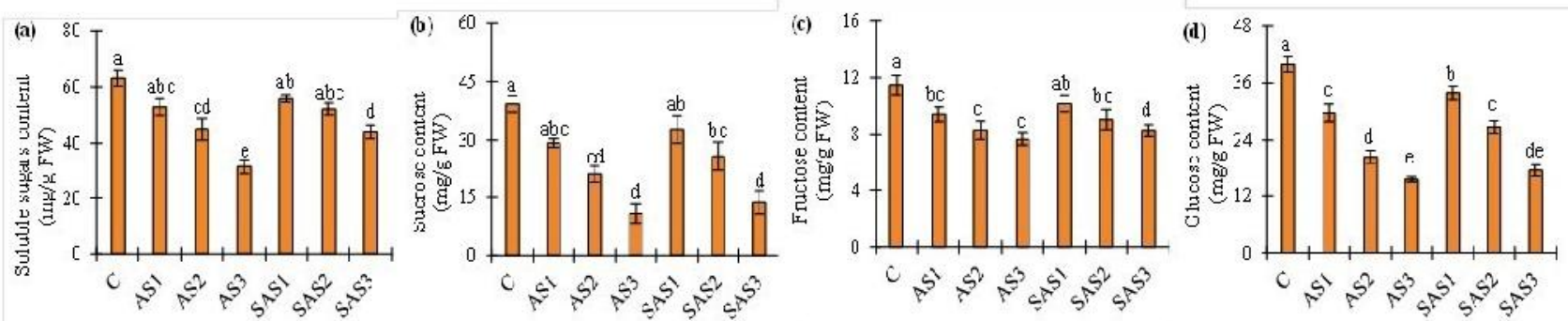

Fig. 5. Effects of alkaline and salt-alkaline stresses on soluble sugars (a), sucrose (b), fructose (c), and glucose (d) contents of shoot in sainfoin. Four-week-old seedlings were treatment with modified Hoagland nutrient solution supplemented without (control, C) or with $50 \mathrm{mM} \mathrm{NaHCO}_{3}$ (alkali stress 1, AS1), $100 \mathrm{mM}$ $\mathrm{NaHCO}_{3}$ (alkali stress 2, AS2), $150 \mathrm{mM} \mathrm{NaHCO}$ (alkali stress 3, AS3), $25 \mathrm{mM} \mathrm{NaCl}+25 \mathrm{mM} \mathrm{NaHCO}$

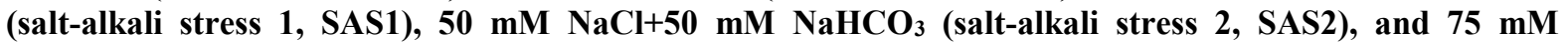
$\mathrm{NaCl}+75 \mathrm{mM} \mathrm{NaHCO}$ (salt-alkali stress 3, SAS3) for $7 \mathrm{~d}$. Three plants were pooled in each replicate. Values are means $\pm \mathrm{SE}(n=8)$ and bars represent $\mathrm{SE}$. Columns with different letters represent significant differences at $P<0.05$ (Duncan's test). FW - fresh weight.

Table 3. Effects of alkaline and salt-alkaline stresses on $\mathrm{Na}^{+}$and $\mathrm{K}^{+}$concentrations, and $\mathrm{K}^{+} / \mathrm{Na}^{+}$ratio of shoot and root in sainfoin. Four-week-old seedlings were treated with modified Hoagland nutrient solution supplemented without (control, C) or with $50 \mathrm{mM} \mathrm{NaHCO}_{3}$ (alkali stress $1, \mathrm{AS1}$ ), $100 \mathrm{mM} \mathrm{NaHCO}$ (alkali stress 2, AS2), $150 \mathrm{mM} \mathrm{NaHCO}$ (alkali stress 3, AS3), $25 \mathrm{mM} \mathrm{NaCl}+25 \mathrm{mM} \mathrm{NaHCO}$ (salt-alkali

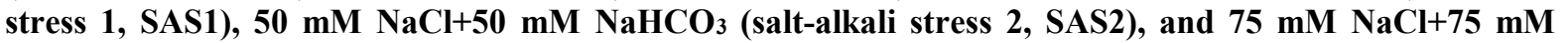
$\mathrm{NaHCO}_{3}$ (salt-alkali stress 3 , SAS3) for $7 \mathrm{~d}$. Three plants were pooled in each replicate. Values are means $\pm \mathrm{SE}(n=8)$. Within each column, means followed by different letters are significantly different at $P<$ 0.05 (Duncan's test). DW - dry weight.

\begin{tabular}{|c|c|c|c|c|c|c|}
\hline \multirow[b]{2}{*}{ Treatment } & \multicolumn{3}{|c|}{ Shoot } & \multicolumn{3}{|c|}{ Root } \\
\hline & $\begin{array}{c}\mathrm{K}^{+}(\mathrm{mmol} / \mathrm{g} \\
\mathrm{DW})\end{array}$ & $\begin{array}{c}\mathrm{Na}^{+}(\mathbf{m m o l} / \mathrm{g} \\
\text { DW) }\end{array}$ & $\mathbf{K}^{+} / \mathbf{N a}^{+}$ratio & $\begin{array}{c}\mathrm{K}^{+}(\mathbf{m m o l} / \mathbf{g} \\
\text { DW) }\end{array}$ & $\begin{array}{c}\mathrm{Na}^{+}(\mathbf{m m o l} / \mathrm{g} \\
\text { DW) }\end{array}$ & $\mathrm{K}^{+} / \mathbf{N a}^{+}$ratio \\
\hline $\mathrm{C}$ & $0.91 \pm 0.05 \mathrm{a}$ & $0.39 \pm 0.09 \mathrm{f}$ & $2.84 \pm 0.34 \mathrm{a}$ & $0.94 \pm 0.05 \mathrm{a}$ & $0.45 \pm 0.09 \mathrm{c}$ & $2.33 \pm 0.29 \mathrm{a}$ \\
\hline AS1 & $0.81 \pm 0.03 \mathrm{ab}$ & $0.71 \pm 0.06 \mathrm{de}$ & $1.17 \pm 0.10 \mathrm{ab}$ & $0.74 \pm 0.04 \mathrm{ab}$ & $0.69 \pm 0.07 \mathrm{bc}$ & $1.19 \pm 0.21 \mathrm{~b}$ \\
\hline AS2 & $0.63 \pm 0.05 \mathrm{c}$ & $1.06 \pm 0.07 \mathrm{bc}$ & $0.62 \pm 0.08 \mathrm{bcd}$ & $0.61 \pm 0.05 \mathrm{bcd}$ & $0.82 \pm 0.08 \mathrm{abc}$ & $0.79 \pm 0.10 b c$ \\
\hline AS3 & $0.41 \pm 0.02 \mathrm{~d}$ & $1.47 \pm 0.10 \mathrm{a}$ & $0.29 \pm 0.02 \mathrm{~d}$ & $0.34 \pm 0.05 \mathrm{~d}$ & $1.16 \pm 0.23 \mathrm{a}$ & $0.31 \pm 0.02 \mathrm{~d}$ \\
\hline SAS1 & $0.83 \pm 0.04 \mathrm{ab}$ & $0.61 \pm 0.06$ ef & $1.41 \pm 0.10 \mathrm{ab}$ & $0.76 \pm 0.04 \mathrm{ab}$ & $0.62 \pm 0.07 \mathrm{bc}$ & $1.19 \pm 0.15 \mathrm{~b}$ \\
\hline SAS2 & $0.66 \pm 0.05 \mathrm{bc}$ & $0.88 \pm 0.06 \mathrm{~cd}$ & $0.76 \pm 0.06 \mathrm{bc}$ & $0.63 \pm 0.04 \mathrm{bc}$ & $0.66 \pm 0.05 \mathrm{bc}$ & $0.98 \pm 0.10 \mathrm{~b}$ \\
\hline SAS3 & $0.43 \pm 0.03 \mathrm{~d}$ & $1.16 \pm 0.10 \mathrm{~b}$ & $0.38 \pm 0.04 \mathrm{~cd}$ & $0.41 \pm 0.03 \mathrm{~cd}$ & $0.93 \pm 0.03 \mathrm{ab}$ & $0.45 \pm 0.05 \mathrm{~cd}$ \\
\hline
\end{tabular}


Acknowledgements: This work was partially funded by the National Natural Science Foundation of China (Grant no. 31860404) and the Natural Science Foundation of Gansu Province (Grant no. 18JR3RA152).

\section{REFERENCES}

Alvarez-Acosta, C., A. Marrero-Dominguez, L. GalloLlobet and A.M. Gonzalez-Rodriguez (2018). Physiological response of selected avocados (Persea americana) subjected to $\mathrm{NaCl}$ and $\mathrm{NaHCO}_{3}$ stress. Sci. Hortic. 237: 81-88.

Aebi, H. (1984). Catalase in vitro. Methods Enzymol. 105: 121-126.

Bao, A.K., S.M. Wang, G.Q. Wu, J.J. Xi, J.L. Zhang and C.M. Wang (2009). Overexpression of the Arabidopsis $\mathrm{H}^{+}$-PPase enhanced resistance to salt and drought stress in transgenic alfalfa (Medicago sativa L.). Plant Sci. 176: 232-240.

Bates, L.S., R.P. Waldren and I.D. Teare (1973). Rapid determination of free proline for water-stress studies. Plant Soil 39: 205-207.

Bejaoui, F., J.J. Salas, I. Nouairi, A. Smaoui, C. Abdelly, E. Martínez-Force and N.B. Youssef (2016) Changes in chloroplast lipid contents and chloroplast ultrastructure in Sulla carnosa and Sulla coronaria leaves under salt stress. J. Plant Physiol. 198: 32-38.

Bhattarai, S., B. Coulman, A.D. Beattie and B. Biligetu (2018). Assessment of sainfoin (Onobrychis viciaefolia Scop.) germplasm for agromorphological traits and nutritive value. Grass Forage Sci. 73: 958-966.

Beauchamp, C. and I. Fridovich (1971) Superoxide dismutase: improved assays and an assay applicable to acrylamide gels. Anal. Biochem. 44: 276-287.

Gong, B., D. Wen, K. Vandenlangenberg, M. Wei, F. Yang, Q. Shi and X. Wang (2013). Comparative effects of $\mathrm{NaCl}$ and $\mathrm{NaHCO}_{3}$ stress on photosynthetic parameters, nutrient metabolism, and the antioxidant system in tomato leaves. Sci. Hortic. 157:1-12.

Jia, X., H. Wang, S. Svetla, Y. Zhu, Y. Hu, L. Cheng and T. Zhao (2019). Comparative physiological responses and adaptive strategies apple Malus halliana to salt, alkali and saline-alkali stress. Sci. Hortic. 245:154-162.

Khalid, M.F., S. Hussain, M.A. Anjum, S. Ahmad, M.A. Ali, S. Ejaz and R. Morillon (2020) Better salinity tolerance in tetraploid vs diploid volkamer lemon seedlings is associated with robust antioxidant and osmotic adjustment mechanisms. J. Plant Physiol. 244: 153071.

Li, Y., B. Liu, Y. Peng, C. Liu, X. Zhang, Z. Zhang, W. Liang, F. Ma and C. Li (2020). Exogenous
GABA alleviates alkaline stress in Malus hupehensis by regulating the accumulation of organic acids. Sci. Hortic. 261: 108982.

Liu, H., Q.Q. Wang, M.M. Yu, Y.Y. Zhang, Y.B. Wu and H.X. Zhang (2008). Transgenic salt-tolerant sugar beet (Beta vulgaris L.) constitutively expressing an Arabidopsis thaliana vacuolar $\mathrm{Na}^{+} / \mathrm{H}^{+}$antiporter gene, AtNHX3, accumulates more soluble sugar but less salt in storage roots. Plant Cell Environ. 31: 1325-1334.

Nakano, Y. and Y. Asada (1981). Hydrogen peroxide is scavenged by ascorbate-specific peroxidase in spinach chloroplasts. Plant Cell Physiol. 22: 867-880.

Sakharov, I.Y. and G.B. Ardila (1999). Variation of peroxidase activity in cacao (Theobroma cacao L.) beans during their ripening, fermentation and drying. Food Chem. 65: 51-54.

Shen, S., X. Chai, Q. Zhou, D. Luo, Y. Wang and Z. Liu (2019). Development of polymorphic EST-SSR markers and genome of sainfoin (Onobrychis viciaefolia). PeerJ 7: e6542.

Sperdouli, L. and M. Moustakas (2012). Interaction of proline, sugars, and anthocyanins during photosynthetic acclimation of Arabidopsis thaliana to drought stress. J. Plant Physiol. 169: 577-585.

Sun, J., L. He and T. Li (2019) Response of seedling growth and physiology of Sorghum bicolor (L.) Moench to saline saline-alkali stress. PLoS ONE 14: e0220340.

Wu, G.Q., S. Jia, H.L. Liu, C.M. Wang and S.J. Li (2017a). Effect of salt stress on growth, ion accumulation, and distribution in sainfoin seedling. Pratacultural Science 34:1661-1668 (In Chinese).

Wu, G.Q., H.L. Liu, R.J. Feng, C.M. Wang and Y.Y. Du (2017b). Silicon ameliorates the adverse effects of salt stress on sainfoin (Onobrychis viciaefolia) seedlings. Plant Soil Environ. 63: 545-551.

Wu, G.Q., H. Li, C.R. Lei, J. Jin, L.Y. Lin and S.J. Li (2019). Effects of additional $\mathrm{KCl}$ on growth and physiological characteristics of sainfoin (Onobrychis viciaefoia) under high salt stress. Acta Prataculturae Sinica 28: 45-55 (In Chinese).

Wang, H., Z. Wu, Y. Chen, C. Yang and D. Shi (2011). Effects of salt and alkali stresses on growth and ion balance in rice (Oryza sativa L.). Plant Soil Environ. 57: 286-294.

Wang, C.M., J.L. Zhang, X.S. Liu, Z. Li, G.Q. Wu, J.Y. Cai, T.J. Flowers and S.M. Wang (2009). Puccinellia tenuiflora maintains a low $\mathrm{Na}^{+}$ level under salinity by limiting unidirectional $\mathrm{Na}^{+}$influx resulting in a high selectivity for $\mathrm{K}^{+}$ 
over $\mathrm{Na}^{+}$. Plant Cell Environ. 32: 486-496.

Xu, J., T. Liu, S. Yang, X. Jin, F. Qu, N. Huang and X. $\mathrm{Hu}$ (2019). Polyamines are involved in GABAregulated salinity-alkalinity stress tolerance in muskmelon. Environ. Exp. Bot. 164: 181-189.

Zhang, Z., K. He, T. Zhang, D. Tang, R. Li and S. Jia (2019). Physiological responses of Goji berry
(Lycium barbarum L.) to saline-alkaline soil from Qinghai region, China. Sci. Rep. 9: 12057.

Zhang, Z.J., H.Z. Li, W.J. Zhou, Y. Takeuchi and K. Yoneyama (2006). Effect of 5-aminolevulinic acid on development and salt tolerance of potato (Solanum tuberosum L.) microtubers in vitro. Plant Growth Regul. 49: 27-34. 